ISSN 1392-3196 / e-ISSN 2335-8947

Zemdirbyste-Agriculture, vol. 103, No. 3 (2016), p. 273-280

DOI 10.13080/z-a.2016.103.035

\title{
Grain chemical composition of different varieties of winter cereals
}

\author{
Saulius ALIJOŠIUS ${ }^{1}$, Gintautas Juozas ŠVIRMICKAS², Saulius BLIZNIKAS ${ }^{2}$, \\ Romas GRUŽAUSKAS ${ }^{1}$, Vilma ŠAŠYTE ${ }^{1}$, Asta RACEVIČIŪTĖ-STUPELIENË ${ }^{1}$, \\ Vilma KLIŠEVIČIŪTĖ', Agila DAUKŠIENE் ${ }^{1}$ \\ ${ }^{1}$ Lithuanian University of Health Sciences \\ Tilžès 18, Kaunas, Lithuania \\ E-mail: saulius.alijosius@1smuni.lt \\ ${ }^{2}$ Institute of Animal Science, Lithuanian University of Health Sciences \\ R. Žebenkos 12, Baisogala, Radviliškis distr., Lithuania
}

\begin{abstract}
The objective of this research was to evaluate the chemical composition of grain of 20 winter wheat, rye and triticale varieties grown in Lithuania. The grain of the tested varieties was analysed for crude protein, crude fat, crude ash, crude fibre, and amino acids. The Pearson's correlation coefficient between the components of grain chemical composition (except amino acids) was calculated. The highest concentration of crude protein was determined for the variety 'SW Talentro' (triticale) and the lowest for the rye variety 'Palazzo' $(P<0.05)$. Among the wheat varieties tested, the 'Mariboss' contained the highest concentration of crude fat $(1.56 \%$ dry matter $)$ and crude fibre $(2.19 \%$ dry matter $)(P<0.05)$. Among the rye varieties tested, the highest and dominant mean content of neutral detergent fibre was determined for the variety 'Matador' $(20.59 \%$ dry matter $)(P<0.05)$. The grain of wheat varieties had a high content of acid detergent fibre ('Rigi') and acid detergent lignin ('Mariboss') $(P<$ 0.05). Furthermore, a very strong correlation was determined between individual fibre fractions of grain, that is between hemicellulose and neutral detergent fibre content $(r=0.99)$ and between acid detergent fibre and cellulose $(r=0.93)$. A negative correlation was determined between the crude protein and nitrogen-free extract $(r=-0.83)$. The study revealed that the wheat variety 'Zentos', the rye variety 'Dankowskie Amber' and the tirticale variety 'SW Talentro' accumulated a higher amount of amino acids in comparison with the other cereal varieties tested. The results of the study showed that the chemical composition (crude protein, essential amino acids, nitrogenfree extract, neutral detergent fibre) of grain of the triticale varieties was more similar to that of wheat varieties compared with rye varieties.
\end{abstract}

Key words: amino acids, cereal varieties, correlation, fibre fractions.

\section{Introduction}

Cereal grains provide most of the calories and proteins consumed worldwide. The current annual world production is more than 2.5 billion tons. This output is either directly channeled to the food industry or used as animal feed to provide meats, dairy, and poultry products. Among cereals, rice, wheat, and maize yield approximately $89 \%$ of the total production and constitute the mainstay of practically all cultures. The other less important cereals are barley, oats, sorghum, rye, triticale and millets. All cereals are starchy foods and contain protein that does not meet the essential amino acid balance required by growing infants. They are considered as good source of energy, most B vitamins, and dietary fibre when consumed as whole grains. Cereal grains help to reduce the risk of certain types of cancer and coronary heart disease (Serna-Saldivar, 2016). More than half of the world's protein supply is provided by the grain of cereal species, especially wheat, rice, maize and barely and also by a wider range of cereal species (Békés, Wrigley, 2016).

Cereal crops are cultivated worldwide in diverse environments, ranging from warm lowlands to temperate highlands (Lage et al., 2008), including Lithuania. Botanically cereal grains belong to the grass (Poaceae) family that includes wheat, rice, barley, oats and rye. Cereal endosperm flour contains approximately $70-80 \%$ starch, $5-15 \%$ protein and $0.5-4 \%$ non-starch polysaccharides (Topping, 2007). Cereal grain yield is a complex of multi component character and is greatly influenced by various environmental conditions. Grain chemical composition (including amino acids) of different cereal varieties depends on various factors such as grain size, sowing time (Kong et al., 2014) genotype, climate conditions (Janušauskaitè et al., 2013), environment (Akçura et al., 2011), fertilisation, soil conditions (Manès et al., 2012). These parameters can affect chemical characteristics 
of cereal grains, including their energy content, crude protein, fibre fractions or minerals (Rodehutscord et al., 2016).

There is a wide range of cereal varieties, and many of them are grown in Lithuania, therefore it is very important to comprehensively evaluate the chemical composition of grain of different cereal varieties and to determine which ones have improved chemical constitution. Twenty varieties of winter wheat, rye and triticale grown in Lithuania were investigated with the focus on the composition of amino acids and fibre fractions (neutral detergent fibre, acid detergent fibre, acid detergent lignin) in grain.

\section{Material and methods}

Sample collection and preparation. Grain samples of the varieties of winter wheat and winter triticale were collected from the Kaunas Plant Variety Testing Station (PVTS) and winter rye - from Plungè PVTS. Six wheat varieties, seven rye varieties and seven triticale varieties were used for this study. Analysis of the growth parameters of cereals is shown in Table 1. The growth peculiarities, vegetation period, plant height, grain yield in $t^{h a^{-1}}, 1000$ grain weight were evaluated. Varieties differed moderately to widely in quality depending on the trait. Grain yield ranged from $6.90 \mathrm{tha}^{-1}$ (rye 'Matador') to $12.39 \mathrm{t} \mathrm{ha}^{-1}$ (triticale 'Remiko'). A thousand grain weight varied from $40.58 \mathrm{~g}$ (triticale 'Grenado') to $55.31 \mathrm{~g}$ (triticale 'SW Talentro'). Wheat and triticale were fertilised with $\mathrm{N}_{11} \mathrm{P}_{22} \mathrm{~K}_{55}$, additionally with $\mathrm{N}_{68.8}+\mathrm{N}_{68.8}$ : the soil characteristics were: humus $-1.65 \%, \mathrm{pH}-7.6$, $\mathrm{P}_{2} 0_{5}-140 \mathrm{mg} \mathrm{kg}^{-1}, \mathrm{~K}_{2} 0-327 \mathrm{mg} \mathrm{kg}^{-1}$. Rye was fertilised with $\mathrm{N}_{13} \mathrm{P}_{26} \mathrm{~K}_{66}$, additionally with $\mathrm{N}_{69}+\mathrm{N}_{86}$ and the soil characteristics were: humus $-1.87 \%, \mathrm{pH}-5.4, \mathrm{P}_{2} \mathrm{O}_{5}-$
$205 \mathrm{mg} \mathrm{kg}^{-1}, \mathrm{~K}_{2} 0-197 \mathrm{mg} \mathrm{kg}^{-1}$. During the experimental year (2014), the average temperature ranged from $8.9^{\circ} \mathrm{C}$ at tillering to $18.5^{\circ} \mathrm{C}$ at waxy maturity stage of cereals. The rainfall level was between 1 and $100.2 \mathrm{~mm}$ during different development stages of the cereals (http://www. meteo.lt/). The winter wheat and triticale were sown on 27 September 2013. The winter rye was sown on 25 September 2013. Grain samples were harvested in JulyAugust 2014.

Chemical analyses. Grain samples were taken and analysed in accordance with the Commission regulation (EU) No 691/2013 of 19 July 2013 amending Regulation (EC) No 152/2009 as regards methods of sampling and analysis. Grain samples with three subsamples for chemical analyses were ground in an Ultra Centrifugal Mill model ZM 100 (Retsch $\mathrm{GmbH}$, Germany) with $1.0 \mathrm{~mm}$ sieve. Dry matter of grain samples was determined by drying in an oven at $105^{\circ} \mathrm{C}$ until a constant weight and dry matter yield was calculated. Crude protein content was determined by the Kjeldahl method, and conversion factors of 5.7 for wheat and for other grains 6.25 were used to convert total nitrogen to crude protein. Crude fat was extracted with petroleum ether (boiling range of $40-60^{\circ} \mathrm{C}$ ) by the Soxhlet extraction method. Crude ash was determined by incineration in a muffle furnace at $550^{\circ} \mathrm{C}$ for $3 \mathrm{~h}$ (Commission Regulation (EC) No. 152/2009). Crude fibre was determined as the residue after sequential treatment with hot $\mathrm{H}_{2} \mathrm{SO}_{4}$ (conc. $1.25 \%$ ) and hot $\mathrm{NaOH}$ (1.25\%) according to Weende method by Fibertec 2023 FiberCap system (Foss Tecator AB, Sweden). The samples were subjected to the fibre component analyses for ANKOM 220 Fiber Analyzer (ANKOM Technology, USA): acid detergent fibre (ADF) and neutral detergent

Table 1. Characteristics of different varieties

\begin{tabular}{|c|c|c|c|c|c|c|c|}
\hline Variety denomination & $\begin{array}{l}\text { Country } \\
\text { of origin }\end{array}$ & $\begin{array}{l}\text { Grain } \\
\text { yield } \\
\mathrm{t} \mathrm{ha}^{-1} \\
\end{array}$ & $\begin{array}{c}1000 \text { grain } \\
\text { weight } \\
\text { g }\end{array}$ & $\begin{array}{c}\text { Vegetation } \\
\text { period, } \\
\text { days }\end{array}$ & $\begin{array}{c}\text { Cold } \\
\text { resistance } \\
\text { in points }\end{array}$ & $\begin{array}{l}\text { Lodging } \\
\text { resistance } \\
\text { in points }\end{array}$ & $\begin{array}{c}\text { Plant } \\
\text { height } \\
\mathrm{cm}\end{array}$ \\
\hline \multicolumn{8}{|c|}{ Wheat } \\
\hline 'Agil' & Germany & 7.92 & 52.23 & 198 & 7 & 9 & 82 \\
\hline 'Kovas DS' & Lithuania & 9.10 & 46.91 & 201 & 7 & 9 & 87 \\
\hline 'Mariboss’' & Denmark & 10.44 & 41.15 & 205 & 8 & 9 & 93 \\
\hline 'Mulan' & Germany & 8.22 & 47.47 & 199 & 6 & 9 & 97 \\
\hline 'Rigi’ & Switzerland & 8.51 & 42.22 & 199 & 8 & 9 & 93 \\
\hline 'Zentos' & Germany & 8.48 & 47.27 & 204 & 8 & 9 & 122 \\
\hline \multicolumn{8}{|c|}{ Rye } \\
\hline 'Brasetto' & Germany & 9.17 & 44.31 & 193 & 7 & 9 & 131 \\
\hline 'Dankowskie Amber' & Poland & 8.41 & 43.09 & 194 & 8 & 8 & 130 \\
\hline ‘KWS Magnifico’’ & Germany & 9.19 & 43.14 & 194 & 7 & 8 & 129 \\
\hline 'Matador' & Germany & 6.90 & 46.19 & 194 & 6 & 8 & 134 \\
\hline 'Palazzo’' & Germany & 9.27 & 44.92 & 194 & 7 & 9 & 129 \\
\hline 'SU Stakkato’ & Germany & 9.90 & 44.00 & 194 & 8 & 8 & 123 \\
\hline 'Virgiai' & Lithuania & 8.34 & 43.24 & 195 & 9 & 7 & 144 \\
\hline \multicolumn{8}{|c|}{ Triticale } \\
\hline 'Adverdo' & Netherlands & 11.17 & 41.35 & 203 & 9 & 9 & 106 \\
\hline 'Grenado’ & Poland & 11.61 & 40.58 & 199 & 9 & 9 & 94 \\
\hline 'Remiko' & Poland & 12.39 & 43.80 & 199 & 9 & 9 & 119 \\
\hline 'Sequenz' & Germany & 12.08 & 48.94 & 196 & 9 & 9 & 110 \\
\hline 'SU Agendus' & Germany & 11.19 & 45.02 & 204 & 6 & 9 & 99 \\
\hline 'SW Talentro' & Germany & 11.46 & 55.31 & 199 & 8 & 9 & 97 \\
\hline 'Toledo' & Poland & 12.11 & 51.34 & 204 & 9 & 9 & 108 \\
\hline
\end{tabular}


fibre (NDF) and acid detergent lignin (ADL) using a cell wall detergent fractionation method according to van Soest (Faithfull, 2002). Nitrogen-free extract (NFE) was calculated as follows: NFE $(\%)=100-($ moisture $\%+$ crude protein $\%+$ crude fat $\%+$ crude ash $\%+$ crude fibre \%) (Serna-Saldivar, 2012). The content of cell wall structural carbohydrates hemicellulose and cellulose was calculated as the following differences: cellulose $=\mathrm{ADF}$ - ADL and hemicellulose $=$ NDF - ADF (Hindrichsen et al., 2006).

Analyses of amino acids were performed by AccQ-Tag method (Waters..., 1993). For these analyses we used Shimadzu (Shimadzu Corp., Japan) low pressure gradient HPLC system consisting of solvent delivery module LC-10AT $\mathrm{VP}_{\mathrm{vP}}$, auto injector SIL-10AD $\mathrm{VP}_{\mathrm{vP}}$ column oven CTO-10AC $\mathrm{AP}_{\mathrm{VP}}$, spectrofluorometric detector RF$10 \mathrm{~A}_{\mathrm{XL}}$, system controller SCL-10A $\mathrm{A}_{\mathrm{VP}}$, on-line degasser DGU-14A, and for HPLC system control and data collection Workstation LC Solution (Shimadzu Corp., Japan). Chromatographic separation by reversed-phase HPLC was carried out with a Waters AccQ-Tag NovaPak C18, $4 \mu \mathrm{m}, 150 \times 3.9 \mathrm{~mm}$ chromatography column at temperature $37^{\circ} \mathrm{C}$. For separation, $10 \mu \mathrm{L}$ of derivatives were injected. Separated derivatives were detected at Ex $250 \mathrm{~nm}-$ Em $395 \mathrm{~nm}$. A gradient flow was used for separation of amino acid derivatives. Flow rate was set at $1.0 \mathrm{~mL} \mathrm{~min}{ }^{-1}$. The mobile phase consisted of eluent A (prepared from Waters AccQ Tag Eluent A concentrate by diluting of $100 \mathrm{~mL}$ of concentrate to $1 \mathrm{~L}$ of ultrapure water), eluent B (acetonitrile) and eluent C (ultrapure water) (Waters..., 1993).

Statistical analysis. Statistical significance was established using one-way analysis of variance ( $A N O V A)$, and the data were reported as a mean of standard deviation. Mean comparison and separation were done using Duncan's $t$-test $(P<0.05)$. ANOVA and Pearson's correlation analysis were conducted using the statistical package SPSS 22. Means in the same column with different superscript letters are significantly different.

\section{Results and discussion}

Chemical composition. The chemical composition of grain of 20 varieties of cereals is presented in Table 2. The mean crude protein content for all varieties of cereals ranged from $9.40 \%$ DM (rye 'Palazzo') to $12.51 \%$ DM (dry matter) (triticale 'SW Talentro'). Among the wheat varieties, the grain of 'Zentos' accumulated the highest amount of crude protein $(11.71 \% \mathrm{DM})$, whereas the lowest quantity of crude protein was determined for 'Kovas DS' $(10.36 \%$ DM) $(P<0.05)$. Our results are in agreement with those of Liatukas et al. (2012), who found that the protein concentration in the grain of the five winter wheat varieties ('Zentos', 'Kovas DS', 'Zunda DS', 'Kaskada DS' and 'Vikaras DS') ranged from $10.9 \%$ to $12.4 \% \mathrm{DM}$. In rye and triticale grain, the concentration of crude protein was especially high for the varieties 'Virgiai' and 'SW Talentro', respectively. In our

Table 2. Chemical composition of grain (\% dry matter)

\begin{tabular}{|c|c|c|c|c|c|}
\hline Variety denomination & Crude protein & Crude fat & Crude fibre & NFE & Crude ash \\
\hline \multicolumn{6}{|c|}{ Wheat } \\
\hline 'Agil' & $11.00 \mathrm{bc}$ & $1.34 \mathrm{~d}$ & $1.66 \mathrm{~d}$ & $73.76 \mathrm{a}$ & $1.30 \mathrm{a}$ \\
\hline 'Kovas DS' & $10.36 \mathrm{~d}$ & $1.53 \mathrm{~b}$ & $1.62 \mathrm{e}$ & $74.86 \mathrm{a}$ & $1.05 \mathrm{~d}$ \\
\hline 'Mariboss' & $10.82 \mathrm{c}$ & $1.56 \mathrm{a}$ & $2.19 \mathrm{a}$ & $72.94 \mathrm{a}$ & $1.17 \mathrm{c}$ \\
\hline 'Mulan' & $11.56 \mathrm{a}$ & $1.47 \mathrm{c}$ & $1.75 \mathrm{c}$ & $73.31 \mathrm{a}$ & $1.19 \mathrm{~b}$ \\
\hline 'Rigi' & $11.30 \mathrm{ab}$ & $1.13 \mathrm{f}$ & $1.63 \mathrm{e}$ & $74.05 \mathrm{a}$ & $1.31 \mathrm{a}$ \\
\hline 'Zentos' & $11.71 \mathrm{a}$ & $1.31 \mathrm{e}$ & $1.92 \mathrm{~b}$ & $73.06 \mathrm{a}$ & $1.04 \mathrm{e}$ \\
\hline Mean & 11.13 & 1.39 & 1.80 & 73.66 & 1.18 \\
\hline $\mathrm{SD}$ & \pm 0.50 & \pm 0.16 & \pm 0.22 & \pm 0.72 & \pm 0.12 \\
\hline \multicolumn{6}{|c|}{ Rye } \\
\hline 'Brasetto' & $10.07 \mathrm{~b}$ & $1.40 \mathrm{~b}$ & $1.03 \mathrm{~d}$ & $76.43 \mathrm{a}$ & $1.01 \mathrm{f}$ \\
\hline 'Dankowskie Amber' & $11.23 \mathrm{a}$ & $1.13 \mathrm{f}$ & $0.94 \mathrm{e}$ & $75.10 \mathrm{a}$ & $1.13 \mathrm{~d}$ \\
\hline ‘KWS Magnifico’ & $10.11 \mathrm{~b}$ & $1.34 \mathrm{c}$ & $1.25 \mathrm{~b}$ & $75.14 \mathrm{a}$ & $1.16 \mathrm{c}$ \\
\hline 'Matador' & $10.37 \mathrm{~b}$ & $1.56 \mathrm{a}$ & $0.80 \mathrm{f}$ & $76.99 \mathrm{a}$ & $1.31 \mathrm{a}$ \\
\hline ‘Palazzo' & $9.40 \mathrm{c}$ & $1.20 \mathrm{~d}$ & $1.35 \mathrm{a}$ & $76.41 \mathrm{a}$ & $0.75 \mathrm{~g}$ \\
\hline 'SU Stakkato’' & $10.19 \mathrm{~b}$ & $1.15 \mathrm{e}$ & $1.36 \mathrm{a}$ & $76.73 \mathrm{a}$ & $1.10 \mathrm{e}$ \\
\hline 'Virgiai' & $11.25 \mathrm{a}$ & $1.35 \mathrm{c}$ & $1.16 \mathrm{c}$ & $74.61 \mathrm{a}$ & $1.26 \mathrm{~b}$ \\
\hline Mean & 10.37 & 1.30 & 1.13 & $75.92 \mathrm{a}$ & 1.10 \\
\hline $\mathrm{SD}$ & \pm 0.66 & \pm 0.15 & \pm 0.21 & \pm 0.94 & \pm 0.18 \\
\hline \multicolumn{6}{|c|}{ Triticale } \\
\hline 'Adverdo' & $9.81 \mathrm{ef}$ & $1.07 \mathrm{~d}$ & $1.51 \mathrm{~b}$ & $75.69 \mathrm{a}$ & $1.63 \mathrm{a}$ \\
\hline 'Grenado' & $10.17 \mathrm{de}$ & $1.18 \mathrm{c}$ & $1.02 \mathrm{e}$ & $76.33 \mathrm{a}$ & $1.43 \mathrm{f}$ \\
\hline 'Remiko’' & $9.45 \mathrm{f}$ & $1.17 \mathrm{c}$ & $1.02 \mathrm{e}$ & $77.51 \mathrm{a}$ & $1.33 \mathrm{~g}$ \\
\hline 'Sequenz' & $10.40 \mathrm{~d}$ & $1.37 \mathrm{a}$ & $1.61 \mathrm{a}$ & $74.53 \mathrm{a}$ & $1.55 \mathrm{c}$ \\
\hline 'SU Agendus' & $11.89 \mathrm{~b}$ & $1.34 \mathrm{~b}$ & $1.39 \mathrm{c}$ & $73.26 \mathrm{a}$ & $1.58 \mathrm{~b}$ \\
\hline 'SW Talentro' & $12.51 \mathrm{a}$ & $1.01 \mathrm{e}$ & $1.37 \mathrm{~d}$ & $73.11 \mathrm{a}$ & $1.51 \mathrm{~d}$ \\
\hline 'Toledo' & $11.31 \mathrm{c}$ & $1.17 \mathrm{c}$ & $1.38 \mathrm{~cd}$ & $74.64 \mathrm{a}$ & $1.45 \mathrm{e}$ \\
\hline Mean & 10.79 & 1.19 & 1.33 & 75.01 & 1.50 \\
\hline $\mathrm{SD}$ & \pm 1.14 & \pm 0.13 & \pm 0.23 & \pm 1.61 & \pm 0.10 \\
\hline
\end{tabular}

Note. Means in the same column with different superscript letters are significantly different, a-g $-P<0.05$; SD - standard deviation, NFE - nitrogen-free extract. 
study, the level of crude protein was lower compared with the results reported by other authors. Kliseviciute et al. (2014) stated that crude protein content among the different varieties of triticale ranged between $10.47 \%$ DM 'Tulus' and 13.74\% DM 'Lego'. Rakha et al. (2011) have indicated that the content of crude protein in cereals (triticale varieties), grown in different sites, could vary: the protein content in the grain of triticale grown in Sweden in Kölbäck was $14.9 \%$ DM, whereas that of triticale grown in another site in Svalöv was 13.0\% DM. Kowieska et al. (2011) reported that crude protein content was $11.70 \% \mathrm{DM}$ in triticale winter varieties grown in Poland, and these results agree with the findings of our study. Žilic et al. (2011) identified protein content of $9.29-13.96 \%$ DM in rye varieties.

The analysis of crude fat in the grain revealed that the highest values were identified for wheat (the mean $1.39 \%$ DM, among them the highest content was established for the variety 'Mariboss') and the lowest in the triticale (the mean $1.19 \% \mathrm{DM}$, among them the highest content was established for the variety 'Sequenz'). The NFE consists of carbohydrates, sugars, starches and a major portion of materials classified as hemicellulose. The mean NFE concentration ranged from $73.66 \%$ DM for wheat varieties to $75.92 \% \mathrm{DM}$ for rye varieties. The concentrations of NFE were in general agreement with the data of Anjum et al. (2014), who reported, that for 19 different varieties of wheat the NFE in grain ranged from $78.78 \%$ to $82.92 \%$ DM. Our results showed that the wheat varieties grown in Lithuania had lower concentration of NFE. As shown in Table 2, the mean level of crude ash for the triticale varieties is $1.50 \% \mathrm{DM}$ and for the rye varieties $-1.10 \% \mathrm{DM}$. The highest concentration of crude ash was determined in the grain of the triticale varieties 'Adverdo' (1.63\% DM) and 'SU Agendus' (1.58\% DM) and the lowest in 'Remiko' (1.33\% DM) and 'Grenado' $(1.43 \% \mathrm{DM})$. In contrast of our study, Rodehudscord et al. (2016) determined a higher concentration of crude ash in different varieites of wheat $(1.61 \% \mathrm{DM})$, triticale $(1.80 \% \mathrm{DM})$ and rye $(1.72 \% \mathrm{DM})$.

The content of different fibre fractions is presented in Table 3. The NDF content in grain varied between the different cereal varieties The concentration of NDF in the grain of wheat varieties ranged between $11.59 \%$ DM ('Agil') and 13.79\% DM ('Mulan'). The NDF content was the highest for the rye variety 'Matador' $(20.59 \% \mathrm{DM})$ and the lowest for the 'Brasetto' $14.79 \%$ DM $(P<0.05)$. Among the studied grain of triticale varieties, 'Sequenz' had the highest content of NDF $(13.10 \% \mathrm{DM})$ and the lowest NDF level was found in 'SU Agendus' $(10.32 \%$ DM) $(P<0.05)$. Wheat varieties showed the highest mean contents of ADF and ADL. The results of the present study showed lower concentrations of NDF in the grain of rye and triticale varieties than

Table 3. Different fibre fractions of grain ( $\%$ dry matter)

\begin{tabular}{|c|c|c|c|c|c|}
\hline Variety denomination & NDF & $\mathrm{ADF}$ & $\mathrm{ADL}$ & Celullose & Hemicelullose \\
\hline \multicolumn{6}{|c|}{ Wheat } \\
\hline 'Agil' & $11.59 \mathrm{f}$ & $3.12 \mathrm{f}$ & $0.91 \mathrm{f}$ & $2.21 \mathrm{e}$ & $8.47 \mathrm{~d}$ \\
\hline 'Kovas DS' & $13.28 \mathrm{~b}$ & $3.16 \mathrm{e}$ & $0.95 \mathrm{e}$ & $2.21 \mathrm{e}$ & $10.12 \mathrm{a}$ \\
\hline 'Mariboss' & $12.31 \mathrm{~d}$ & $3.68 \mathrm{~b}$ & $1.26 \mathrm{a}$ & $2.42 \mathrm{c}$ & $8.63 \mathrm{~b}$ \\
\hline 'Mulan' & $13.79 \mathrm{a}$ & $3.64 \mathrm{c}$ & $1.18 \mathrm{c}$ & $2.46 \mathrm{~b}$ & $10.15 \mathrm{a}$ \\
\hline ‘Rigi’ & $12.43 \mathrm{c}$ & $3.85 \mathrm{a}$ & $0.97 \mathrm{~d}$ & $2.88 \mathrm{a}$ & $8.58 \mathrm{c}$ \\
\hline 'Zentos' & $11.95 \mathrm{e}$ & $3.57 \mathrm{~d}$ & $1.19 \mathrm{~b}$ & $2.38 \mathrm{~d}$ & $8.38 \mathrm{e}$ \\
\hline $\begin{array}{l}\text { Mean } \\
\text { SD }\end{array}$ & $\begin{array}{l}12.56 \\
\pm 0.83\end{array}$ & $\begin{array}{c}3.50 \\
\pm 0.30\end{array}$ & $\begin{array}{c}1.08 \\
\pm 0.15\end{array}$ & $\begin{array}{c}2.43 \\
\pm 0.25\end{array}$ & $\begin{array}{c}9.06 \\
\pm 0.84\end{array}$ \\
\hline \multicolumn{6}{|c|}{ Rye } \\
\hline 'Brasetto' & $14.79 \mathrm{~g}$ & $2.69 \mathrm{e}$ & $0.80 \mathrm{e}$ & $1.89 \mathrm{~d}$ & $12.10 \mathrm{~g}$ \\
\hline 'Dankowskie Amber' & $19.29 \mathrm{~b}$ & $2.59 \mathrm{f}$ & $0.80 \mathrm{e}$ & $1.79 \mathrm{f}$ & $16.70 \mathrm{~b}$ \\
\hline ‘KWS Magnifico’ & $18.01 \mathrm{c}$ & $3.15 \mathrm{a}$ & $0.97 \mathrm{c}$ & $2.18 \mathrm{a}$ & $14.86 \mathrm{c}$ \\
\hline 'Matador' & $20.59 \mathrm{a}$ & $2.89 \mathrm{~d}$ & $0.70 \mathrm{f}$ & $2.19 \mathrm{a}$ & $17.70 \mathrm{a}$ \\
\hline 'Palazzo’' & $15.22 \mathrm{f}$ & $3.02 \mathrm{~b}$ & $1.10 \mathrm{~b}$ & $1.92 \mathrm{c}$ & $12.20 \mathrm{f}$ \\
\hline 'SU Stakkato' & $15.77 \mathrm{e}$ & $2.97 \mathrm{c}$ & $1.12 \mathrm{a}$ & $1.85 \mathrm{e}$ & $12.80 \mathrm{e}$ \\
\hline 'Virgiai' & $16.14 \mathrm{~d}$ & $2.88 \mathrm{~d}$ & $0.87 \mathrm{~d}$ & $2.01 \mathrm{~b}$ & $13.26 \mathrm{~d}$ \\
\hline $\begin{array}{c}\text { Mean } \\
\text { SD }\end{array}$ & $\begin{array}{l}17.12 \\
\pm 2.21 \\
\end{array}$ & $\begin{array}{c}2.88 \\
\pm 0.19 \\
\end{array}$ & $\begin{array}{c}0.91 \\
\pm 0.16 \\
\end{array}$ & $\begin{array}{c}1.98 \\
\pm 0.16 \\
\end{array}$ & $\begin{array}{l}14.23 \\
\pm 2.24 \\
\end{array}$ \\
\hline \multicolumn{6}{|c|}{ Triticale } \\
\hline 'Adverdo' & $11.70 \mathrm{c}$ & $2.82 \mathrm{c}$ & $1.07 \mathrm{a}$ & $1.75 \mathrm{~d}$ & $8.88 \mathrm{c}$ \\
\hline 'Grenado' & $10.58 \mathrm{f}$ & $2.50 \mathrm{f}$ & $0.73 \mathrm{~g}$ & $1.77 \mathrm{c}$ & $8.08 \mathrm{f}$ \\
\hline 'Remiko' & $11.26 \mathrm{~d}$ & $2.57 \mathrm{~d}$ & $0.81 \mathrm{f}$ & $1.76 \mathrm{c}$ & $8.69 \mathrm{~d}$ \\
\hline 'Sequenz' & $13.10 \mathrm{a}$ & $2.90 \mathrm{a}$ & $1.02 \mathrm{c}$ & $1.88 \mathrm{~b}$ & $10.20 \mathrm{a}$ \\
\hline 'SU Agendus' & $10.32 \mathrm{~g}$ & $2.57 \mathrm{~d}$ & $1.05 \mathrm{~b}$ & $1.52 \mathrm{f}$ & $7.75 \mathrm{~g}$ \\
\hline 'SW Talentro' & $12.18 \mathrm{~b}$ & $2.86 \mathrm{~b}$ & $0.85 \mathrm{e}$ & $2.01 \mathrm{a}$ & $9.32 \mathrm{~b}$ \\
\hline 'Toledo' & $10.97 \mathrm{e}$ & $2.54 \mathrm{e}$ & $0.89 \mathrm{~d}$ & $1.65 \mathrm{e}$ & $8.43 \mathrm{e}$ \\
\hline $\begin{array}{l}\text { Mean } \\
\text { SD }\end{array}$ & $\begin{array}{l}11.44 \\
\pm 0.97\end{array}$ & $\begin{array}{c}2.68 \\
\pm 0.17\end{array}$ & $\begin{array}{c}0.92 \\
\pm 0.13\end{array}$ & $\begin{array}{c}1.76 \\
\pm 0.16\end{array}$ & $\begin{array}{c}8.76 \\
\pm 0.82\end{array}$ \\
\hline
\end{tabular}

Note. Means in the same column with different superscript letters are significantly different; a-g $-P<0.05 ; \mathrm{SD}-$ standard deviation; $\mathrm{NDF}$ - neutral detergent fibre, ADF - acid detergent fibre, ADL - acid detergent lignin. 
those recorded in some earlier studies of Žilic et al. (2011), Mullenix et al. (2014) and Kaplan et al. (2015). A higher amount of NDF in the grain of wheat, rye and triticale varieties was reported by Kowieska et al. (2011), Anjum et al. (2014) and Kaplan et al. (2014).

Composition of amino acids. The present study showed the differences in the profile of amino acids of analysed grain of wheat, rye and triticale varieties (Table 4). Cereal grains and legumes constitute a major source of protein in the human diet (Comai et al., 2007). People, as well as animals, are able to synthesise only 9 (non-essential) out of the 22 amino acids. The remaining amino acids (essential amino acids) must be provided in food. Wheat and triticale protein is characterised by a high content of exogenic amino acids, whose germs compose a valuable component of functional foods (Sidhu et al., 2007). According to the present study, the mean content of amino acids in wheat grain is higher than that in rye or triticale grain. The mean content of lysine, obtained in the present study, was relatively lower from 3.22 (wheat) to 3.01 (triticale) $\mathrm{g} \mathrm{kg}^{-1} \mathrm{DM}$ than that reported by Kowieska et al. (2011). The analysed wheat, rye and triticale varieties differ among themselves to a statistically significant degree in the content of essential amino acids: lysine, threonine, isoleucine, valine, leucine, phenylalanine and tyrosine $(P<0.05)$.

Our investigation once again confirmed that cereal grains are poor in lysine, but make up an optimal source of sulphuric amino acids, which was confirmed earlier. When calculating the total amino acids concentration in the grain

Table 4. The contents of dispensable amino acids in the grain of the cereal varieties $\left(\mathrm{g} \mathrm{kg}^{-1}\right.$ dry matter)

\begin{tabular}{|c|c|c|c|c|c|c|c|c|c|c|c|c|c|c|c|c|}
\hline $\begin{array}{c}\text { Variety } \\
\text { denomination }\end{array}$ & Lys & Met & Thr & Ile & Val & Leu & His & Phe & Tyr & Arg & Asp & Ser & Glu & Pro & Gly & Ala \\
\hline
\end{tabular}

Wheat

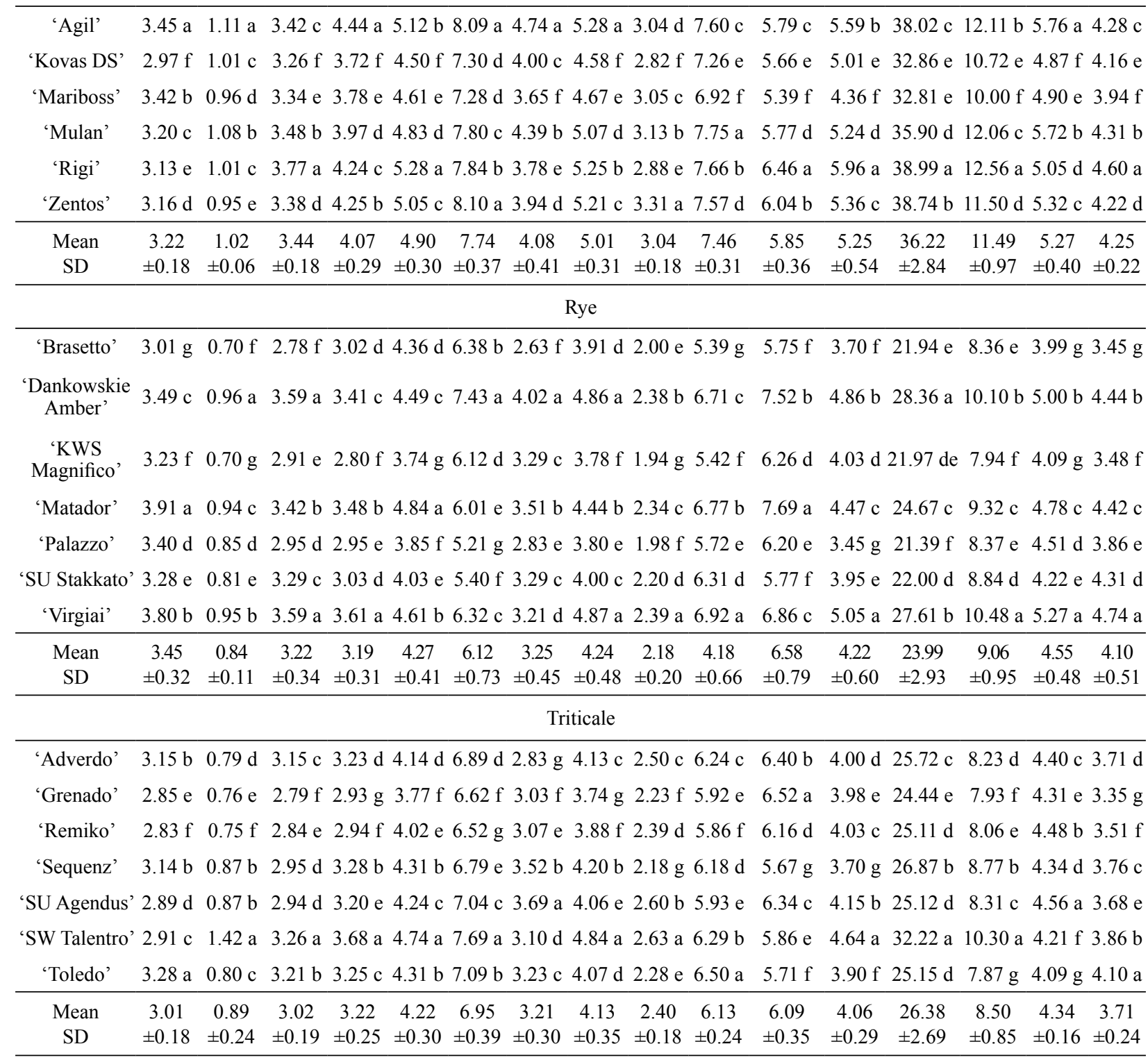

Note. Means in the same column with different superscript letters are significantly different; a-g $-P<0.05$; SD - standard deviation; Lys - lysine, Met - methionine, Thr - threonine, Ile - isoleucine, Val - valine, Leu - leucine, His - histidine, Phe - phenylalanine, Tyr - tyrosine, Arg - arginine, Asp - asparagine, Ser - serine, Glu - glutamic acid, Pro - proline, Gly - glycine, Ala - alanine. 
of wheat varieties, the lowest value was determined for 'Mariboss' - $103.09 \mathrm{~g} \mathrm{~kg}^{-1}$ and the highest - $118.45 \mathrm{~g} \mathrm{~kg}^{-1}$ for 'Rigi'; among the rye varieties the lowest content was determined for 'Palazzo' - $81.33 \mathrm{~g} \mathrm{~kg}^{-1}$ and the highest for 'Dankowskie Amber' - $101.61 \mathrm{~g} \mathrm{~kg}^{-1}$; for triticale varieties the lowest in 'Grenado' - $85.16 \mathrm{~g} \mathrm{~kg}^{-1}$ and the highest - $101.66 \mathrm{~g} \mathrm{~kg}^{-1}$ for 'SW Talentro'. Kliševičiūtè (2014) reported that for wheat varieties the mean glutamic acid concentration was $32.99 \mathrm{~g} \mathrm{~kg}^{-1}$, proline $-9.73 \mathrm{~g} \mathrm{~kg}^{-1}$, leucine $-6.82 \mathrm{~g} \mathrm{~kg}^{-1}$. Zafar et al. (2014) determined that

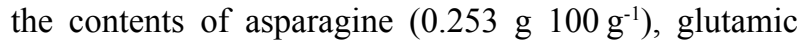

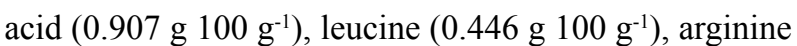

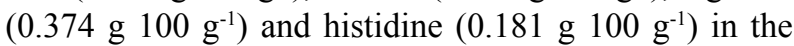
triticale grain were lower than the maximum values observed in this study.

Correlations of parameters. In addition to the presented results (Table 5), statistical analysis of the data also confirmed a very strong correlation between the hemicellulose and NDF contents $(r=0.99)$. These results were in agreement with those of Hossain et al. (2013). A negative correlation between the crude protein and NFE $(r=-0.83)$ was determined. A low correlation between

Table 5. Pearson's correlation coefficients between the main nutritional properties of grain $(\mathrm{n}=20)$

\begin{tabular}{|c|c|c|c|c|c|c|c|c|c|c|}
\hline Parameters & Protein & $\begin{array}{c}\text { Crude } \\
\text { fat }\end{array}$ & $\begin{array}{l}\text { Crude } \\
\text { fibre }\end{array}$ & $\mathrm{NDF}$ & $\mathrm{ADF}$ & $\mathrm{ADL}$ & NFE & $\begin{array}{c}\text { Crude } \\
\text { ash }\end{array}$ & Cellulose & Hemicellulose \\
\hline Protein & 1.00 & & & & & & & & & \\
\hline Crude fat & -0.06 & 1.00 & & & & & & & & \\
\hline Crude fibre & 0.31 & 0.24 & 1.00 & & & & & & & \\
\hline NDF & -0.20 & 0.24 & $-0.49^{*}$ & 1.00 & & & & & & \\
\hline $\mathrm{ADF}$ & 0.23 & 0.34 & $0.75^{* *}$ & -0.02 & 1.00 & & & & & \\
\hline $\mathrm{ADL}$ & 0.11 & 0.17 & $0.84 * *$ & -0.26 & $0.64 * *$ & 1.00 & & & & \\
\hline NFE & $-0.83^{* *}$ & $-0.25^{*}$ & $-0.73 * *$ & 0.38 & $-0.61 * *$ & -0.44 & 1.00 & & & \\
\hline Crude ash & 0.29 & -0.27 & 0.05 & $-0.43^{*}$ & -0.34 & -0.22 & -0.20 & 1.00 & & \\
\hline Cellulose & 0.23 & 0.34 & $0.52 * *$ & 0.11 & $0.93 * *$ & 0.31 & $-0.54 *$ & -0.31 & 1.00 & \\
\hline Hemicellulose & -0.23 & 0.20 & $-0.59 * *$ & $0.99 * *$ & -0.16 & -0.35 & $0.46^{*}$ & -0.38 & -0.24 & 1.00 \\
\hline
\end{tabular}

$*-P<0.05, * *-P<0.01$ significantly different; NDF - neutral detergent fibre, ADF - acid detergent fibre, ADL - acid detergent lignin, NFE - nitrogen-free extract

crude fat and individual fibre fractions (ADF and ADL) were estimated for the grain tested $(r=0.17-0.34)$. The ADF content in grain showed positive correlations with cellulose $(r=0.93)$.

Scientists identified highly significant positive correlation among fibre components, including ADF, NDF and ADL. Cardinal et al. (2003) in sheaths of grains found larger correlations between NDF and ADF $(r=$ $0.84)$, NDF and ADF $(r=0.96)$. In the present study, we did not find significant correlation of ADL with either ADF or NDF.

\section{Conclusions}

1. Considerable differences in grain chemical composition of different winter wheat, rye and triticale varieties grown in Lithuania were determined. The highest content of crude protein was determined in the grain of the winter triticale varieties 'SW Talentro' and 'SU Agendus' $-12.51 \%$ and $11.89 \%$ dry matter (DM), recpectively, but the highest mean amount of crude protein was identified in the grain of wheat varieties $(11.71 \% \mathrm{DM})$. The highest crude fat and crude fiber values were determined for wheat varieties - the mean amount was $1.39 \%$ and $1.80 \%$ DM, recpectively (the highest content was established for the variety 'Mariboss'). The lowest content of crude fat was in the grain of triticale varieties, it varied from $1.01 \%$ ('SW Talentro') to $1.37 \%$ ('Sequenz') DM. The lowest crude fiber content was found in the grain of rye varieties, it varied from $0.80 \% \mathrm{DM}$ ('Matador') to $1.36 \%$ ('SU Stakkato') DM.

2. The concentration of neutral detergent fibre (NDF) in the grain of the rye variety 'Matador' was the highest $(20.59 \%$ DM) compared to the other rye varieties. The highest contents of acid detergent fibre (ADF) and acid detergent lignin (ADL) were found in the grain of the wheat varieties - 'Rigi' (3.85\% DM) and 'Mariboss' $(1.26 \% \mathrm{DM})$, respectively. The lowest contents of cellulose (including ADF and ADL) and hemicellulose (including NDF and ADF) were found in the grain of triticale varieties - the mean amount $1.76 \%$ and $8.76 \%$ DM, respectively.

3. Our ivestigation confirmed that the grains of winter cereals are poor in lysine, but are an optimal source of sulphuric amino acids. The highest essential amino acid Lys was determined for the rye variety 'Matador' - 3.91 $\mathrm{g} \mathrm{kg}^{-1} \mathrm{DM}$. However, the highest methionine content was determined for wheat variety 'Mulan' $-1.08 \mathrm{~g} \mathrm{~kg}^{-1} \mathrm{DM}$. The lowest total amino acids concentration was detected for the wheat variety 'Mariboss' - $103.09 \mathrm{~g} \mathrm{~kg}^{-1}$ and the highest for 'Rigi' - $118.45 \mathrm{~g} \mathrm{~kg}^{-1}$; among the rye varieties the lowest content of amino acids was in the grain of 'Palazzo' - $81.33 \mathrm{~g} \mathrm{~kg}^{-1}$ and the highest in 'Dankowskie Amber' - $101.61 \mathrm{~g} \mathrm{~kg}^{-1}$; in triticale varieties it was the lowest for the 'Grenado' $-85.16 \mathrm{~g} \mathrm{~kg}^{-1}$ and the highest for the 'SW Talentro' - $101.66 \mathrm{~g} \mathrm{~kg}^{-1}$.

4. The results of our study indicated that chemical composition (crude protein, essential amino acids, nitrogen-free extract, neutral detergent fibre) of grain of triticale varieties was more similar to that of wheat varieties than rye varieties.

5. Cereal grains are the main components of compound feed for animals, and wheat grains can be replaced by triticale grains, because they accumulate a similar level of crude protein, essential amino acids 
leucine, isoleucine, tyrosine, celullose, hemicelullose and acid detergent fibre.

\section{Acknowledgements}

The study was supported by the Research Fund of Lithuanian University of Health Sciences.

Received 24022016

Accepted 26052016

\section{References}

Akçura M., Taner S., Kaya Y. 2011. Evaluation of bread wheat genotypes under irrigated multi-environment conditions using GGE biplot analyses. Zemdirbyste-Agriculture, 98 (1): $35-40$

Anjum M. I., Ghazanfar S., Begum I. 2014. Nutritional composition of wheat grains and straw influenced by differences in varieties grown under uniform agronomic practices. International Journal of Veterinary Science, 3 (3): 100-104

Békés F., Wrigley C. W. 2016. The protein chemistry of cereal grains. Reference Module in Food Science (in press) http://dx.doi.org/10.1016/B978-0-08-100596-5.00101-3

Cardinal A. J., Lee M., Moore K. J. 2003. Genetic mapping and analysis of quantitative trait loci affecting fiber and lignin content in maize. Theoretical and Applied Genetics, 106 (5): 866-874

Comai S., Bertazzo A., Bailoni L., Zancato M., Costa C. V. L., Allegri G. 2007. Non-protein (free and protein-bound) tryptophan content in cereal and legume seed flours. International Congress Serie, 1304: 227-232 http://dx.doi.org/10.1016/j.ics.2007.07.007

Commission Regulation (EC) No. 152/2009. Laying down the methods of sampling and analysis for the official contro of feed <http://www.agriculture.gov.ie/media/migration/ agri-foodindustry/feedingstuffs/compoundfeeds/ ComReg1522009.pdf>

Commission Regulation (EC) No 691/2013 of 19 July 2013 amending Regulation (EC) No 152/2009 as regards methods of sampling and analysis $<\mathrm{http}: / / \mathrm{www}$.iss.it/binary/ogmm/ cont/regolamento 691 2013 campionamento mangimi. pdf $>$

Faithfull N. T. 2002. Methods in agricultural chemical analysis: a practical handbook. USA, $206 \mathrm{p}$. http://dx.doi.org/10.1079/9780851996080.0000

Hindrichsen I. K., Kreuzer M., Madsen J., Bach Knudsen K. E. 2006. Fiber and lignin analysis in concentrate, forage, and feces: detergent versus enzymatic-chemical method. Journal of Dairy Science, 89 (6): 2168-2176 http://dx.doi.org/10.3168/jds.S0022-0302(06)72287-1

Hossain K., Ulven C., Glover K., Ghavami F., Simsek S., Alamri M.S., Kumar A., Mergoum M. 2013. Interdependence of cultivar and environment on fiber composition in wheat bran. Australian Journal of Crop Science, 7 (4): 525-531

Janušauskaitė D., Auškalnienė O., Feizienė D., Feiza V. 2013. Response of common barley (Hordeum vulgare L.) physiological parameters to agricultural practices and meteorological conditions. Zemdirbyste-Agriculture, $100(2): 127-136$ http://dx.doi.org/10.13080/z-a.2013.100.016

Kaplan M., Kökten K., Akçura M. 2014. Determination of silage characteristics and nutritional values of some triticale genotypes. Turkish Journal of Agricultural and Natural Sciences, 1 (2): 102-107
Kaplan M., Yilmaz M. F., Kara R. 2015. Variation in hay yield and quality of new triticale lines. Journal of Agricultural Sciences, 21: 50-60

Kliševičiūte V. 2014. The nutritional value analysis of different genotypes of barley, triticale and wheat and efficiency using of whole cereal grains in broiler chickens feeding: $\mathrm{PhD}$ thesis, Lithuanian University of Health Sciences. Kaunas, Lithuania (in Lithuanian)

Kliseviciute V., Gruzauskas R., Raceviciute-Stupeliene A., Svirmickas G. J. 2014. Nutritional value of triticale and using of whole triticale in the broiler chickens nutrition. Proceedings of the International scientific conference Nutrition, Health and Quality of Food of Animal Origin - Challenges and Opportunities. Kaunas, Lithuania, p. $92-96$

Kong Z., Ye-ju L., Peng Q. 2014. Wheat generation adding in Xundian County of Yunnan Province in summer. Journal of Northeast Agricultural University, 21 (4): 1-9 http://dx.doi.org/10.1016/S1006-8104(15)30013-1

Kowieska A., Lubowicki R., Jaskowska I. 2011. Chemical composition and nutritional characteristics of several cereal grain. Acta Scientiarum Polonorum Zootechnica, 10 (2): $37-50$

Lage J., Trethowan R. M., Hernandez E. 2008. Identification of site similarities in western and central Asia using CIMMYT international wheat yield data. Plant Breeding, 127 (4): $350-354$ http://dx.doi.org/10.1111/j.1439-0523.2007.01411.x

Liatukas Ž., Ruzgas V., Razbadauskienė K., Brazauskas G., Koppel R. 2012. Winter wheat cultivars 'Kovas DS', 'Zunda DS', 'Vikaras DS', 'Kaskada DS' for high input farming: development and characterization. ZemdirbysteAgriculture, 99 (3): 255-264

Manès Y., Gomez H. F., Puhl L., Reynolds M. P., Braun H. J., Trethowan R. 2012. Genetic yield gains of the CIMMYT international semi-arid wheat yield trialsfrom 1994 to 2010. Crop Science, 52 (4): 1543-1552 http://dx.doi.org/10.2135/cropsci2011.10.0574

Mullenix M. K., Dillard S. L., Lin J. C., Gamble B. E., Muntifering R. B. 2014. Evaluation of wheat and triticale forage for stocker production in the Gulf Coast region. The Professional Animal Scientist, 30 (3): 296-304 http://dx.doi.org/10.15232/S1080-7446(15)30120-0

Rakha A., Åman P., Andersson R. 2011. Dietary fiber in triticale grain: variation in content, composition, and molecular weight distribution of extractable components. Journal of Cereal Science, 54 (3): 324-331 http://dx.doi.org/10.1016/j.jcs.2011.06.010

Rodehutscord M., Rückert C., Maurer H. P., Schenkel H., Schipprack W., Knudsen K. E. B., Schollenberger M., Laux M., Eklund M., Siegert W., Mosenthin R. 2016. Variation in chemical composition and physical characteristics of cereal grains from different genotypes. Archives of Animal Nutrition, 70 (2): 87-107 http://dx.doi.org/10.1080/1745039X.2015.1133111

Serna-Saldivar S. O. 2012. Laboratory reference and procedures manual. New York, USA, 368 p.

Serna-Saldivar S. O. 2016. Cereals: types and composition. Reference Module in Food Science, p. 718-723

Sidhu J. S., Kabir Y., Hoffman F. G. 2007. Functional foods from cereal grain. International Journal of Food Properties, 10 (2): $231-244$ http://dx.doi.org/10.1080/10942910601045289

Topping D. 2007. Cereal complex carbohydrates and their contribution to human health. Journal of Cereal Science, 46 (3): $220-229$ http://dx.doi.org/10.1016/j.jcs.2007.06.004 
Waters AccQ-Tag chemistry package (instruction manual). 1993. Waters Corp., Milford, USA

Zafar S., Naz N., Nazir S., Abbas M., Khan A. M. 2014. Analysis of selected amino acids in different varieties of wheat available in Punjab, Pakistan. Chromatography Research International http://dx.doi.org/10.1155/2014/867070
Žilic S., Dodig D., Milašinovic Šeremešic M., Kandic V., Kostadinovic M., Prodanovic S., Savic D. 2011. Small grain cereals compared for dietary fibre and protein contents. Genetika, 43 (2): 381-395

http://dx.doi.org/10.2298/GENSR1102381Z

ISSN 1392-3196 / e-ISSN 2335-8947

Zemdirbyste-Agriculture, vol. 103, No. 3 (2016), p. 273-280

DOI $10.13080 / \mathrm{z}-\mathrm{a} .2016 .103 .035$

\title{
Ivairių veislių žieminių javų grūdų cheminė sudėtis
}

\author{
S. Alijošius ${ }^{1}$, G. J. Švirmickas², S. Bliznikas ${ }^{2}$, R.Gružauskas ${ }^{1}$, V. Šašytè ${ }^{1}$, \\ A. Racevičiūtè-Stupeliené ${ }^{1}$, V. Kliševičiūtè ${ }^{1}$, A. Daukšienè ${ }^{1}$ \\ ${ }^{1}$ Lietuvos sveikatos mokslų universitetas \\ ${ }^{2}$ Lietuvos sveikatos mokslų universiteto Gyvulininkystès institutas
}

\section{Santrauka}

Tyrimo tikslas - ịvertinti Lietuvoje išaugintų 20 veislių žieminių kviečių, rugių ir kvietrugių cheminę sudètį. Siekiant nustatyti juose esantị žalių baltymų, žalių riebalų, žalių pelenų, žalios ląstelienos ir aminorūgščių kiekius, atliktas įvairių javų grūdų tyrimas. Apskaičiuotas javų grūdų cheminès sudėties komponentų (išskyrus aminorūgštis) Pirsono koreliacijos koeficientas. Vertinant visų tirtų veislių javus, didžiausia žalių baltymų koncentracija nustatyta veislès 'SW Talentro' kvietrugiuose, mažiausia -'Palazzo' $(P<0,05)$ rugiuose. Iš visų tirtų kviečių veislių 'Mariboss' grūdai turèjo didžiausią kiekį $(P<0,05)$ žalių riebalų $(1,56 \% \mathrm{SM})$ ir žalios ląstelienos $(2,19 \% \mathrm{SM})$. Iš visų tirtų rugių veislių didžiausias ir dominuojantis vidutinis kiekis $(P<0,05)$ neutralaus detergento tirpale netirpios ląstelienos nustatytas veislès 'Matador' (20,59 \% SM) grūduose. Kviečiu grūdai turèjo didelius kiekius $(P<0,05)$ rūgštaus detergento tirpale netirpios ląstelienos ('Rigi') ir rūgštyje išplauto lignino ('Mariboss'). Taip pat nustatyta itin stipri koreliacija tarp atskirų grūdų ląstelienos frakcijų, t. y. tarp hemiceliuliozès bei neutralaus detergento tirpale netirpios ląstelienos $(r=0,99)$ ir rūgštaus detergento tirpale netirpios ląstelienos bei celiuliozès $(r=0,93)$ kiekių. Neigiama koreliacija $(r=-0,83)$ nustatyta tarp žalių baltymų ir ekstrakto be azoto. Tyrimo rezultatai atskleidè, kad, lyginant su kitomis tirtomis javų veislèmis, veislių 'Zentos' kviečių, 'Dankowskie Amber' rugių ir 'SW Talentro' kvietrugių grūdai sukaupe didesnị kiekị aminorūgščių. Tyrimo duomenimis, ịvairių veislių kvietrugių grūdų cheminè sudėtis (žalių baltymų, pagrindinių aminorūgščių, ekstrakto be azoto, neutralaus detergento tirpale netirpios ląstelienos kiekiai) yra panašesnè į kviečių nei ị rugių veislių grūdų cheminę sudètị.

Reikšminiai žodžiai: aminorūgštys, javų veislès, koreliacija, ląstelienos frakcijos.

Please use the following format when citing the article:

Alijošius S., Švirmickas G. J., Bliznikas S., Gružauskas R., Šašytė V., Racevičiūtė-Stupelienė A., Kliševičiūtė V., Daukšienė A. Grain chemical composition of different varieties of winter cereals. Zemdirbyste-Agriculture, 103 (3): 273-280 DOI 10.13080/z-a.2016.103.035 